\title{
Chapter 24 \\ The Social Dimensions of Biological Invasions in South Africa
}

\author{
Ross T. Shackleton (D), Ana Novoa (D, Charlie M. Shackleton (D, \\ and Christian A. Kull
}

\begin{abstract}
This chapter examines current knowledge relating to the human and social dimensions of biological invasions in South Africa. We do so by advancing 12 propositions and examining the evidence for or against each using South African literature. The propositions cover four broad issues: how people cause invasions; how they conceptualise them; effects of invasive species on people; and peoples' responses to them. The propositions we assess include: (1) intentional introductions were and continue to reflect the social ethos of the time; (2) people go to great lengths to ensure that newly introduced species establish themselves; (3) human-mediated modifications help invasive species to establish; (4) how people think about and study invasive species is strongly shaped by social-ecological contexts; (5) knowledge and awareness of invasive species is low amongst the general public; (6) personal values are the primary factor affecting perceptions of invasive alien species and their control; (7) specific social-ecological contexts mediate how invasive species affect people; (8) research on social effects of invasive species primarily focuses on negative impacts; (9) the negative social impacts of invasive species on local livelihoods are of more concern to people than impacts on biodiversity; (10) people are less willing to manage species regarded as 'charismatic'; (11) social heterogeneity increases conflicts around the management of biological invasions; and (12) engagement with society is key to successful management. By advancing and questioning propositions, we were able to determine what is known, provide evidence for where gaps lie, and thus identify areas for future research.
\end{abstract}

\footnotetext{
R. T. Shackleton $(\bowtie)$

Institute of Geography and Sustainability, University of Lausanne, Lausanne, Switzerland

Centre for Invasion Biology, Stellenbosch University, Stellenbosch, South Africa

e-mail: rtshackleton@gmail.com
}

\author{
A. Novoa \\ Department of Invasion Ecology, Institute of Botany, The Czech Academy of Sciences, \\ Průhonice, Czech Republic \\ C. M. Shackleton \\ Department of Environmental Science, Rhodes University, Makhanda, South Africa \\ C. A. Kull \\ Institute of Geography and Sustainability, University of Lausanne, Lausanne, Switzerland
}

(C) The Author(s) 2020

B. W. van Wilgen et al. (eds.), Biological Invasions in South Africa, Invading

Nature - Springer Series in Invasion Ecology 14,

https://doi.org/10.1007/978-3-030-32394-3_24 


\subsection{Introduction}

Research that addresses the human and social dimensions of invasion science is crucial for understanding and responding to biological invasions as people are involved in all parts of the introduction-naturalisation-invasion-response continuum (Head 2017; Shackleton et al. 2019a). Despite the need for humanities and social science perspectives in invasion science, to date there has been relatively little work in this area (Le Maitre et al. 2004; Vaz et al. 2017a; Abrahams et al. 2019). Consequently, there are many research gaps and missed opportunities for interdisciplinary collaboration which is necessary to truly advance and address pressing challenges in dynamic and varied contexts (Vaz et al. 2017a; Abrahams et al. 2019). To promote uptake, Shackleton et al. (2019a) recently highlighted four broad issues in which research on the human and social dimensions of invasion science can help to improve understanding and guide management responses. These four areas are: (1) how people cause invasions, (2) how people conceptualise and perceive invasions, (3) the effects of invasions on people, and (4) how people respond to invasions.

In this chapter, for each thematic area, we advance three propositions (statements or proposals for consideration and which can help in asserting a generalisable trend or process - similar to a hypothesis) and examine the evidence in support of each of them in the South African context (Table 24.1). We tried to ensure that the propositions were pertinent to current research topics and trends, and to ensure that they would be useful and relevant to guide future work. We used propositions as a means to move beyond just a summary of current knowledge of the social contributions to invasion science towards a more focussed, analytic and critical stance as the necessary foundation for development of knowledge and theory and future research. The process of examining the available evidence for each proposition fosters in-depth thinking of what evidence is available, where different points conflict and where gaps in research persist. The propositions are not specific to South Africa, but the relative richness of research on biological invasions in the country offers a reasonable first opportunity to investigate them.

\subsection{Humans as Causes of Alien Species Invasions}

Humans are the primary agents for the deliberate or inadvertent introduction of alien species outside their native ranges, some of which become invasive. In South Africa, work by historians and, to a lesser degree, by researchers in other social science and humanities disciplines, has detailed the role that people play in facilitating biological invasions. In particular, many purposeful introductions have been driven by specific societal mind-sets or ethos, operating in different eras (Carruthers et al. 2011; Kull et al. 2011; Udo et al. 2019), and humans facilitated the establishment of invasions by modifying species and landscapes. In South Africa and globally, understanding the social drivers and processes of species introductions is probably the best researched of the four thematic areas. 


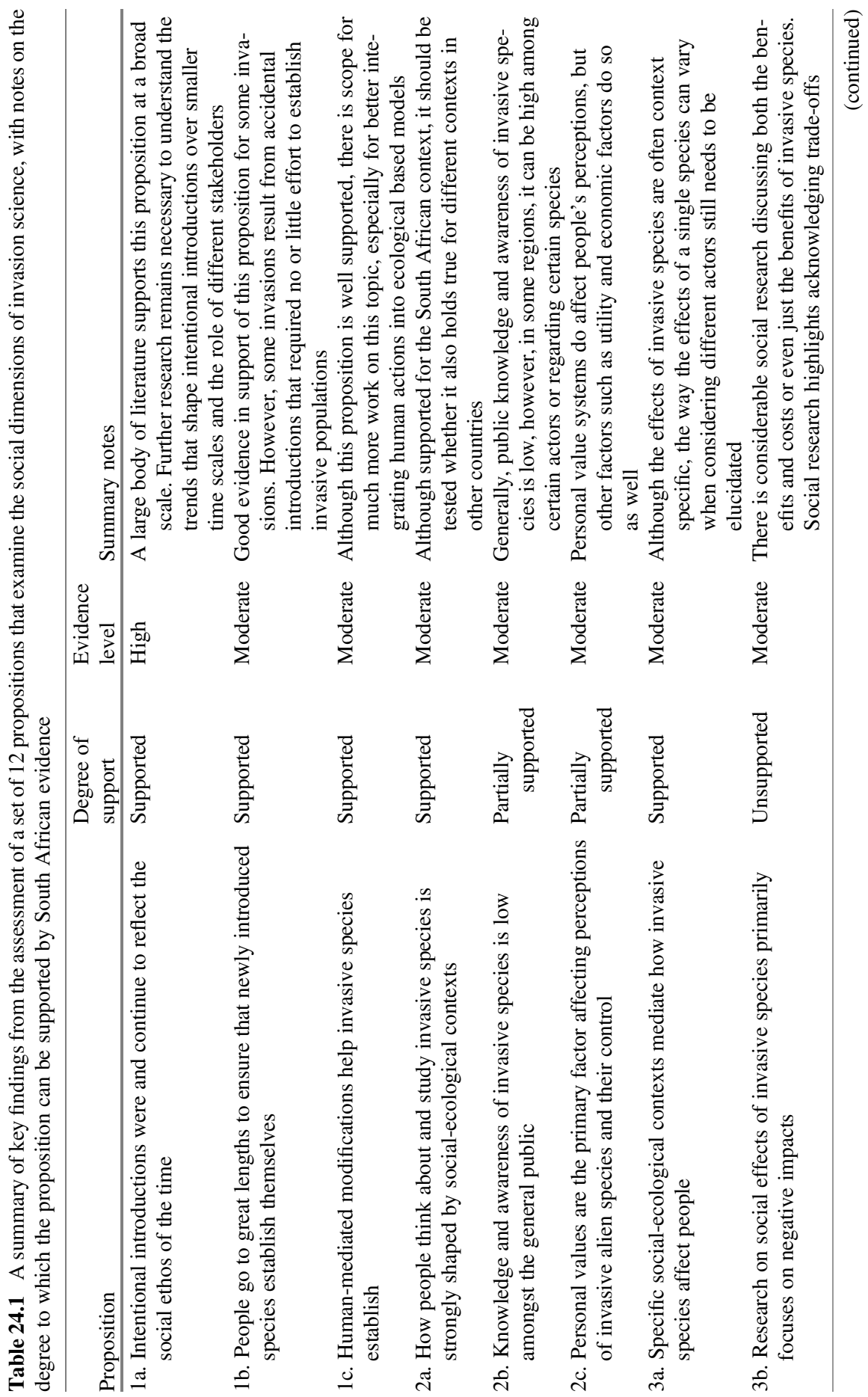




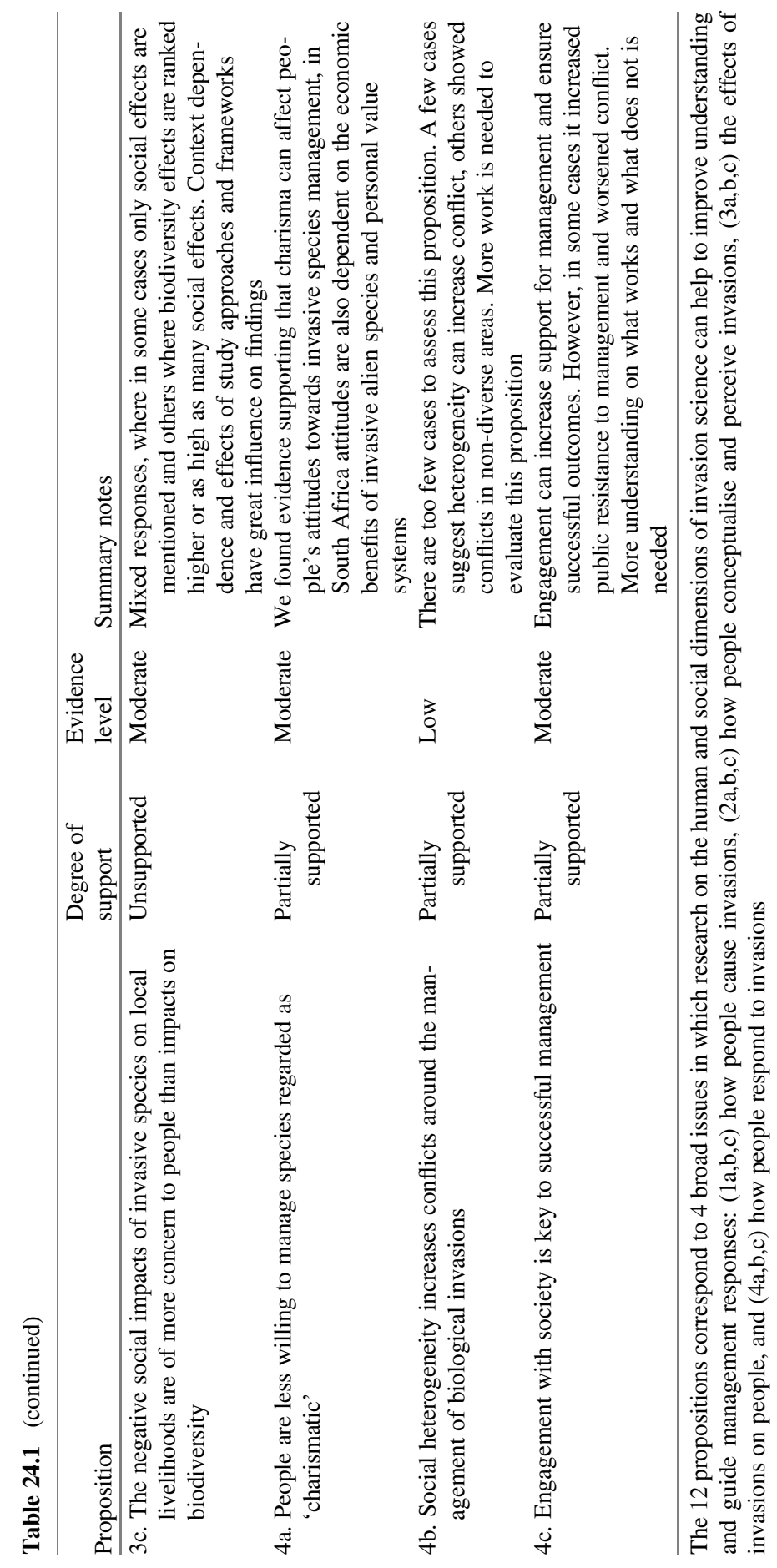




\subsubsection{Proposition 1a: Intentional Introductions Were and Continue to Reflect the Social Ethos of the Time}

A vast number of alien species have been and continue to be purposefully or accidentally introduced into South Africa by people for various reasons (Richardson et al. 2003). Van Sittert (2002) argues that "biological invasions are thus intrinsically historical processes primarily shaped not by the biology of the invader, but by the shifting cultural values of the invaded society". We suggest that most motivations for introductions are driven by an ethos that evolves over time and relates closely to social fashions, political-economic circumstances and scientific paradigms (Carruthers et al. 2011). To discuss this, we highlight differences in motivations for introducing alien species during three broad time periods-but we acknowledge there are subtler trends within the broad timelines we outline.

A substantial number of alien species were introduced and established during the colonial period (Bennett and van Sittert 2019)_often with the ethos of making "improvements" to colony landscapes and economies and for botanical interest (Carruthers et al. 2011). Such introductions were strongly influenced by the broad landscape context of South Africa. For example, many tree species were introduced for forestry, linked to economic development, as the country is poorly endowed with natural forests for timber (Bennett and Kruger 2015). Yet other introductions during this period were driven by emotionally related values - in the then Cape Colony Pinus species (Pines) were planted by settlers in the 1700s, partly to create a sense of place and familiarity within the treeless landscapes. Similarly, Oncorhynchus mykiss (Rainbow Trout) was introduced to improve sense of place and counteract nostalgia for fly fishing by local settler elites from Europe (Alletson 1997; Brown 2013). This phenomenon is emphasised by Thompson (1913) "The Colonialist, especially of British blood, seemed unable to finally settle down in a new land until many of the animals and plants that minister his pleasure or profit in the homeland had followed him...." Canavan et al. (2018) showed that even slaves transported to South Africa during the colonisation by the Dutch East India Company (1652-1795) brought useful species, like bamboos, from their native lands with them. During the colonial period, many aesthetically pleasing species were also transferred between colonies, such as Lantana camara (Lantana), which was seen as an exotic novelty (Kannan et al. 2013). As a result, many former British colonies share similar issues with invasive ornamental plants brought in by colonial settlers. Collecting exotic plants for newly established public or private botanical gardens was a novelty within the colonies, and was a well-remunerated occupation and promoted by acclimatisation societies (Janick 2007).

By the 1900s appreciation and pride for native flora grew substantially and there was less attachment to species of the homeland by settlers (van Sittert 2003; Bennett 2015). By the mid-1900s, species were often introduced or purposefully dispersed in the context of livelihood development or environmental restoration, and promoted on a mass-scale by the state and non-governmental organisations alike (Carruthers et al. 2011), and less so to fulfil a sense of place for elite settlers or for primary 
industry than before. This led to the introduction of many so-called "wonder plants" that could yield multiple benefits for people and ecosystems, but that brought many costs once they became invasive (Low 2012; Kull and Tassin 2012). For example, Prosopis (Mesquite) was promoted in the apartheid era (mid-1900s) by agricultural departments to solve the effects of drought in the arid Northern Cape (Shackleton et al. 2014). Elderly community members recount stories of how agricultural extension officers distributed Prosopis seedlings for planting on private farms and in communal villages (Shackleton and Shackleton 2018). Leucaena leucocephala (Leucaena), was promoted by development, agricultural and forestry-focused NGOs during the 1960s to 1980s as a multipurpose tree (Brewbaker 1987). Similarly, a new set of Australian Acacia species were introduced for dryland restoration (Carruthers et al. 2011). Oreochromis niloticus (Nile Tilapia) was introduced into South Africa in the 1950s for aquaculture, particularly for food security and income generation among poor African communities (Zengeya et al. 2011).

The current ethos (in the post-apartheid democratic area) could facilitate further purposeful introductions. For example, a shift in gardening practices to become less water intensive might lead to the introduction of a new set of non-native species that require little water or care, and yet may become invasive (van Kleunen et al. 2018). Similarly, the rising demand for biofuels and green energy may lead to the promotion of invasive plants such as Jatropha curcas (Physic Nut) (Witt 2010; Blanchard et al. 2011). Species of interest to collectors can easily be bought online (e-commerce trade) which is a modern, easy and novel pathway of potential invasive species (Martin and Coetzee 2011; Humair et al. 2015). Simultaneously, the growing ethos of either managing or preventing invasions might lead to fewer purposeful introductions (Carruthers et al. 2011; Udo et al. 2019), although the context of increasing global movement of people and goods could lead to more accidental introductions than in the past (Seebens et al. 2017). For example, biofouling and ballast water has led to the recent introduction of a number of alien marine species along the South African coastline (Faulkner et al. 2017, 2020, Chap. 12).

Overall, evidence from South Africa supports the proposition that there have been clear changes over time in the ethos for introducing and promoting alien species which follow trends in scientific, historical, political and economic contexts (Carruthers et al. 2011). We illustrate this using a very broad set of temporal scales-and there is further need for understanding and analysing changes at finer spatial and temporal scales (e.g. Bennett 2015). Another important aspect would be to analyse the role of different actors-i.e. maybe too much is contextualised under the broad colonial banner and further comparison between British and Dutch settlers might yield useful insights.

\subsubsection{Proposition 1b: People Go to Great Lengths to Ensure that Newly Introduced Species Become Well Established}

People have put effort into facilitating the establishment and spread of alien species. For example, decades of research went into ensuring that introductions of 
Eucalyptus (Gums) for forestry were successful (Bennett 2011). Australian Acacia species were planted en masse (more than 300 million seeds) to stabilise sand on the Cape flats, and prizes were offered to individuals for successful planting and establishment (van Sittert 2000; Bennett and van Sittert 2019), leading to substantial invasions as a result of this high propagule pressure (Donaldson et al. 2014). Similarly, people made substantial efforts to ensure the establishment of Prosopis trees during the mid-twentieth century for silviculture (Shackleton et al. 2015a). Some farmers recount childhood memories of putting Prosopis seedlings by the Aga stove in winter and only planting them out in spring to ensure survival. But, in the hot summers, one farmer recounts how during the school holidays he was required to go out and water Prosopis seedlings to ensure their survival.

Significant research went into discovering how to introduce fishes for sport and recreation by British colonists, and how to ensure their survival. Tens of thousands of O. mykiss and Salmo trutta (Brown Trout) eggs were sent from the UK to South Africa in the late 1800 s and early 1900 s, which failed to establish, but efforts continued until appropriate strategies were implemented to ensure survival during transport (also see Weyl et al. 2020, Chap. 6). In the Cape, special hatcheries were built and a bounty was even established for killing otters that were presumed to pose a threat to the newly introduced fish (Britz 2015). In KwaZulu-Natal, railway sidings were built specifically to ensure that the water did not have time to heat up during transport (Alletson 1997). The time and money that went into ensuring introduction and survival must have helped to promote invasions in the long run.

The available evidence and examples above support the proposition that great perseverance and effort to ensure the survival and establishment of some non-native species was important for facilitating invasions. The degree of human tenacity during the pre-introduction and post-introduction stages is typically poorly accounted for in purely ecological models of invasion dynamics.

\subsubsection{Proposition 1c: Human-Mediated Modifications Help Invasive Species to Establish}

Humans can modify both species and landscapes, which may facilitate or limit the invasion of some species (Kueffer 2017; Shackleton et al. 2018). Human agency is often not well acknowledged in the biological sciences, often being treated as an "unwelcome extraneous variable", but is actually a key factor in explaining many biological invasion processes (van Sittert 2002).

Le Roux et al. (2013) show how humans have altered the genetic make-up of Acacia pycnantha (Golden wattle) through artificial selection both prior to and after introduction, which may facilitate its invasiveness. At a broader scale, human alteration or disturbance of landscapes has facilitated invasions. Initially, many invasive species can only survive and proliferate in human-altered landscapes. For example, the creation of ponds, urban garden microclimates and farm dams has 
aided the invasion of frogs in South Africa (Davies et al. 2013; Measey et al. 2017). Similarly, the distribution of the invasive bird Acridotheres tristus (Common Myna) in South Africa is closely tied to large urban areas (Peacock et al. 2007; Measey et al. 2020, Chap. 5). Environmental degradation and land use change also affects invasions (Kueffer 2017). In South Africa, overstocking of domestic livestock helped Opuntia ficus-indica (Mission Prickly Pear) to become a dominant in the Eastern Cape-"farmers became increasingly aware of their own hand in the gradual transformation of the landscape around them, so opuntia intruded from the margins to the centre" (van Sittert 2002). In the marine context, Carcinus maenas (Green Crab) has established and become invasive only in human-made harbours and small bays nearby because the species cannot maintain a grip on rocks under high wave action (Mabin et al. 2017). In South Africa one of the 26 inter-basin transfer schemes (i.e. channels or tunnels constructed to link different river systems) has aided the spread of at least five non-native species (Ellender et al. 2014).

These few examples show that human modifications of species and landscapes can facilitate invasions, supporting our proposition. This shows some support to the "passenger" part of the driver vs passenger debate-whereby degradation might facilitate invasions rather than invasions causing initial degradation. Despite this, a lot more work can be done on how human modifications facilitate invasions and maybe incorporating this more into models would be useful (e.g. niche modelling, Vimercati et al. 2017; Walker et al. 2017).

\subsection{People's Conceptulisation and Perceptions of Invasive Alien Species}

A fast-growing body of literature in the field of invasion science considers how people view and conceptualise invasive species, both from a theoretical level to more of a personal and individual level (Kull et al. 2011, 2019; Estévez et al. 2015; Shackleton et al. 2019b). South Africa provides a fertile testing ground for different theories within this topic due to its diverse social and ecological contexts.

\subsubsection{Proposition 2a: How People Think About, Value and Study Invasive Species is Strongly Shaped by Social-ecological Contexts}

Historical, geographical, ecological, social and institutional contexts help to determine how people think about invasive species. For instance, attention to biological invasions is weak in South America (Speziale et al. 2012), whereas in colonial island landscapes, settings of rapid ecological change caused by the settlers as well as strong scientific interest by the same people, environmental concerns rose to the fore (Grove 1995). Such influence is also apparent in South Africa, where concern over 
invasions historically arose out of the particular ecological and social context of the Cape Colony (Pooley 2014), an influence that evolved with different periodic ethos (Carruthers et al. 2011), and which continues to this day. As noted by Bennett and van Sittert (2019), "One fact dominates the history of invasive plants in South Africa. The Cape has consistently led national planning and action on weeds and alien invasive species, especially relating to agricultural weeds and invasive trees." $\mathrm{We}$ expand on four key aspects relating to this important statement: (1) the focus on Cape biota, (2) the focus on trees, (3) the national spread of the invasion concept, and (4) the institutional structures that embody and permit this dominance.

First, Cape 'exceptionalism', both real and perceived, shapes South African understanding of the phenomena of biological invasions. The distinctive ecology of the Cape, with the Fynbos Biome, combined with its strategic location and early history of European settlement, became the epicentre for species introductions and attracted a lot of scientific attention (Bennett and van Sittert 2019). In this context, scientific concern about the impact of introduced plants on the Fynbos Biome emerged in the late nineteenth century, and this concern continues, fortified with references to the Cape having one of the six global 'Floristic Kingdoms' (Lidström et al. 2016). One consequence is that invasion science research in South Africa has emphasised plants.

Second, a peculiarity of invasion science in South Africa is its focus on trees. The dearth of native forests in the Fynbos Biome, not to mention in the country's vast Grassland and Karoo Biomes, led to particularly strong efforts during the 19th and 20th centuries to introduce and promote trees (Brown 2013; Bennett 2011). These in turn led to highly visible, landscape-transforming invasions and the early catalysts for nascent invasion research and policy in South Africa (Bennett and van Sittert 2019). Possibly as a result, other invasive growth forms, like grasses, have received less attention than they should have (Milton 2004).

Third, the impact of such trees on fynbos landscapes facilitated the early development of interest in biological invasions beyond agricultural weeds in the Cape. This radiated outward to the national level only in the 1980s-1990s, with new policy openings in South Africa after the end of apartheid coming at the same time that an international conception of invasive species was emerging (Lidström et al. 2016; Bennett and van Sittert 2019). The national Working for Water (WfW) programme drew heavily on hydrological and ecological scientific insights from tree invasions in the Cape as motivating evidence for this poverty-relief project (van Wilgen and Wannenburgh 2016).

Fourth, a consequence of the Cape-based origins of thinking, research, and policy-making on invasions is the deep anchoring of this work in Cape-based institutions. The WfW program "draws its core ideas and leadership from this region" (Bennett 2014), and urban middle-class whites from the Cape have driven the agenda about invasions (Bennett and van Sittert 2019). The primary institution that has gained agenda-setting authority in the field is the Centre for Invasion Biology (C.I.B), a nationally funded Centre of Excellence established in 2004, based at Stellenbosch University (van Wilgen et al. 2014; Lidström et al. 2016; Abrahams et al. 2019; Richardson et al. 2020, Chap. 30). The C.I.B is not only 
important at a national level, but also internationally, where it has strongly shaped the development of invasion science (Pyšek et al. 2006; Pouris 2007; Abrahams et al. 2019). It works closely with the South African National Biodiversity Institute, the Council for Scientific and Industrial Research, WfW and many other partners. A recent bibliometric review of research sponsored by WfW shows that people with C.I.B affiliation—closely overlapping with a Stellenbosch affiliation-(co)authored almost half of this work; and that a small number of Stellenbosch-based C.I.B researchers are core authors who play a strong role in maintaining, mediating, and perhaps even controlling relationships and networks in the field (Abrahams et al. 2019). The C.I.B is built upon local expertise in forestry and botany, and previous programs in biological control and plant protection, and as a result has strongly emphasised, until recently, ecological research over other disciplines (Abrahams et al. 2019; Kull 2018).

This illustrates that specific contexts and events can shape the way people think about invasions. South Africa has a unique story where one region, the Cape, has really shaped what is thought and done today. This suggests that maybe some of the knowledge and theory that is accepted as normal might need to be adapted for different contexts to ensure relevance.

\subsubsection{Proposition 2b: Knowledge and Awareness of Invasive Alien Species is Low Amongst the General Public}

Globally, a growing body of research has focussed on understanding factors that influence people's knowledge and awareness of invasive species. This is an important component in building educational plans and adaptive management strategies (Cole et al. 2019). By knowledge and awareness, we mean what people understand and recognise biological invasions in general but also have knowledge about specific invasive species.

Studies assessing knowledge and perceptions of invasive species in South Africa, display varying results. Despite South Africa being a leading country in terms of policy, outreach and management of biological invasions (Byrne et al. 2020, Chap. 25), $77 \%$ of people in a small city (Makhanda (Grahamstown)), did not know that they had one or more listed invasive alien trees in their garden (Shackleton and Shackleton 2016). A similar number could not name a single invasive plant. Of those who did, they mainly knew of Acacia species or Jacaranda mimosifolia (Jacaranda). This study also suggested that people with higher education and incomes had a broader understanding and knowledge of invasive species. Potgieter et al. (2019), working in Cape Town, highlighted a stark contrast in knowledge levels across different socioeconomic groups, largely as a result of the legacy of apartheid, with more affluent and well-educated citizens having a better knowledge of invasions. 
Focusing on Prosopis, the second most widespread invasive tree genus in South Africa, Shackleton et al. (2015) highlight greater knowledge and understanding by citizens than the previous two studies. The research did take place in areas of high infestation and where native tree biodiversity is very low, which might explain these results. However, differences in knowledge between social settings and actors was evident. Rural commercial farmers and communal land dwellers who had the greatest exposure to Prosopis and whose livelihoods were more closely linked to nature had a much greater knowledge than urban residents. Furthermore, unlike previous studies, Shackleton et al. (2015) revealed greater knowledge of the species amongst poor, urban dwellers (some of whom were reliant on the tree for fuelwood) as compared to affluent urban citizens. Another study in rural villages in the Northern Cape highlighted that knowledge and awareness of invasive species is highly species-dependent (Shackleton and Shackleton 2018). The majority of respondents knew that Prosopis, Eucalyptus and J. mimosifolia were non-native, but very few respondents knew other common invasive alien plants like Schinus molle (Pepper Tree), Tecoma stans (Yellow Bells), Melia azedarach (Seringa), Morus alba (White Mulberry) and O. ficus-indica, despite them being in the same landscape for similar durations. Differing levels of knowledge across species are likely influenced by factors like species traits, residence time, reasons for introduction, rates of spread and densities of invasions, impacts on people as well as management and outreach efforts.

For this proposition, we suggest knowledge of invasions can be contextdependent, and knowledge is generally low except for a few flagship taxa. Similarly, certain sectors of society are more knowledgeable regarding invasions, such as elites, and those living in rural areas who are likely to be more in contact with invasions and their impacts.

\subsubsection{Proposition 2c: Personal Values are the Primary Factor Affecting Perceptions of Invasive Alien Species and Their Control}

Various emotionally-related factors can influence people's attitudes and perceptions of invasive species (Urgenson et al. 2013; Shackleton et al. 2019b). For example, the global literature shows that people often "fall in love" with beautiful, cute or charismatic species due to their emotional appeal, while others might be detested based on their ugliness or threat, such as fire ants, wasps or rats (Shackleton et al. 2019b).

Only a few studies have addressed this question in South Africa. Novoa et al. (2017) illustrated that, in South Africa, there was not much difference in the support for management between different taxa, whereas in the UK, the control of a charismatic animal species was less supported than that of an ornamental plant. This might be linked to differences in attitudes by those living in more rural areas (South Africa), but also to the presence and diversity of native flora and fauna. 
Linking to the rural-urban debate, people in urban areas were more interested and emotionally attached to charismatic species whereas in natural areas perceptions were more based on species utility. This is mirrored by Dickie et al. (2014) and Gaertner et al. (2016) who highlight that, particularly in cities, people's values relate to aesthetic and recreational benefits, and often take precedent over economic ones. In Cape Town, Potgieter et al. (2019) showed that whilst utilitarian and economic factors play a role in shaping perceptions, cultural values (e.g. aesthetic appearance) also helped to explain people's perceptions - suggesting that multiple interacting factors shape people's attitudes. However, in more rural areas, Shackleton et al. (2015) showed that for Prosopis invasions, personal values, whilst important, were not of as much concern as those relating to economic and livelihood benefits and costs. Furthermore, Novoa et al. (2017) indicated that promoting public awareness can assist in changing perceptions and in increasing public support for control, but individuals who are hostile to any invasive species management programs will remain - based on their personal ethical values. Mukwada et al. (2016) discussed how personal or professional values founded on various worldviews and means of living can influence people's perceptions; with park wardens wanting to manage Acacia species around Golden Gate National Park and communal villagers having different opinions on the matter as the trees provide utility value for them. Similar socio-political factors relating to biological invasions and different actors' social anxieties are highlighted by Comaroff and Comaroff (2001).

These examples suggest that, overall, multiple factors might influence people's perceptions of biological invasions, including the landscape context, the stakeholder group, their experiences and the species traits. In South Africa, we suspect that people's perceptions are more likely related to the economic and livelihood effects of invasive species, although intrinsic and emotional aspects cannot be discounted, and are likely to be more prominent in urban areas.

\subsection{The Effects of Invasive Species on People}

Invasive species can affect people positively or negatively in a variety of ways. For instance, invasive species provide both ecosystem services and disservices, which have different implications for livelihoods and human wellbeing (Shackleton et al. 2007; Vaz et al. 2017b; Shackleton et al. 2019c). Seminal works on the role of invasive species on people's livelihoods come from South Africa and have focused on rural settings (de Neergaard et al. 2005; Shackleton et al. 2007).

\subsubsection{Proposition 3a: Specific Social-Ecological Contexts Mediate How Invasive Species Affect People}

The local socioeconomic and ecological context can greatly influence how biological invasions affect people. For example, invasive Acacia species are extremely 
important for local livelihoods in the high-altitude communal grasslands in South Africa, where other trees are rare. Acacia species provide fuelwood, which is a primary source of heating and cooking fuel for almost all rural households (de Neergaard et al. 2005; Shackleton et al. 2007; Aitken et al. 2009). Despite increases in access to electricity in South Africa, Acacia dealbata (Silver Wattle) is still highly important for livelihoods today with almost no change in use levels in the past decade (Ngorima and Shackleton 2019). A number of households also earn incomes from selling the wood. However, when they reach high densities, Acacia species also have negative implications for water resources (Le Maitre et al. 2020, Chap. 15), grazing (O'Connor and van Wilgen 2020, Chap. 16) and people's health and safety (Shackleton et al. 2018). In the relatively treeless Fynbos Biome, invasive tree species are also an important source of fuelwood and income for rural villagers and foresters (Kull et al. 2011). However, this is a fire-prone biome and Pinus species can greatly increase the risk and negative implications of wild fires (Kraaij et al. 2018), highlighting how ecological contexts can result in this unique disservice (Comaroff and Comaroff 2001; Pooley 2014). Shackleton et al. (2015b) show that most local stakeholders from the Karoo and Savanna Biomes prefer to use native trees instead of the invasive Prosopis for fuelwood. In these areas, overall use of Prosopis for fuelwood is declining with increasing access to and use of electricity, unlike in the high-altitude Grassland Biome.

Research on Opuntia ficus-indica invasions in South Africa has provided insights into the complex interaction between invasions and human wellbeing and how benefits and costs are not static in time and space (Novoa et al. 2015a, b; Hill et al. 2020, Sect. 19.3; O'Connor and van Wilgen 2020, Sect. 16.5.5). Opuntia ficus-indica was promoted in arid areas to improve agricultural production (Beinart and Wotshela 2012), and at first it greatly benefited commercial farmers and rural villagers (Beinart and Wotshela 2003). Over time, it became invasive and spread over large areas, and its negative impacts started to outweigh its benefits, leading to control measures to reduce its spread, densities and negative impacts. Biological control was highly successful and reduced its spread and population densities, leading to the lowering of costs and the increase of benefits (Zimmermann and Moran 1991). Currently, with lower densities, $O$. ficus-indica has been adopted into society and provides a number of benefits for poor rural people, particularly through the collection and sale of fruits (Shackleton et al. 2007, 2011), showing the important role of spatial and temporal contexts.

Evidence from South Africa therefore supports this proposition and suggests that the effects of biological invasions on people are influenced by specific social and ecological contexts and can be highly dynamic in space and time. It highlights that in some cases some actors benefit more than others or some impacts are more external to people directly in contact with invasions (such as loss of water for cities downstream). 


\subsubsection{Proposition 3b: Social Science Research on Invasive Species Primarily Focuses on Negative Effects of Invasive Alien Species for People}

Traditionally, ecological research on biological invasions has focussed on negative effects and ignored benefits of invasive species (Tassin and Kull 2015), and therefore we expect that to be similar in the social sciences and humanities.

Unlike ecological studies, two studies in South Africa discussed only the positive aspects of invasive species for local livelihoods and ignored any negative effects. Shackleton et al. (2011) showed the importance of selling O. ficus-indica fruits in rural areas of the Eastern Cape. In the same region the invasive fish Cyprinus carpio (Common Carp) benefits livelihoods, as a source of both food and cash income from the sale of fish (Ellender et al. 2010) — as yet no negative livelihood effects have been investigated from this introduction.

Most other studies acknowledge a suite of benefits and costs and often weigh them against each other. For example, the benefits of $O$. ficus-indica and Australian Acacia species were viewed as greater than the costs to rural communal land villagers (de Neergaard et al. 2005; Shackleton et al. 2007; Beinart and Wotshela 2012) — although some costs were highlighted as well. For Prosopis, both benefits and costs were assessed, and findings indicated that negative impacts outweighed benefits (Wise et al. 2012; Shackleton et al. 2015a). Potgieter et al. (2019) showed that many urban invasives provide both ecosystem services and disservices to people, as is the case for small rural villages in the Kalahari (Shackleton and Shackleton 2018). Harris et al. (2016) argued that work on Columba spp. (Pigeons) has traditionally focused on negative issues and control, but their research actually showed the opposite- that people on the University of South Africa's Muckleneuk campus would rather encourage Pigeons.

On a commercial level, the invasive Mediterranean Mussel (Mytilus galloprovincialis) is an important aquaculture species in South Africa and benefits are acknowledged (Hecht 1992). Similarly, invasive trees used in forestry provide financial benefits and employment (Tewari 2001; Louw 2004; Bennett and Kruger 2015). At the same time, they have negative implications for other livelihood activities and broader society (Le Maitre et al. 2011). For these kinds of species, economic research commonly applies cost-benefit analyses to estimate both positive and negative impacts (de Wit et al. 2001) and better understand conflicts and tradeoffs (van Wilgen and Richardson 2014; Zengeya et al. 2017).

Research that has examined the social effects of invasive species in South Africa is fairly balanced and reports on both positive and negative impacts. This is contrary to our proposition. This also differs substantially from ecological research that tends to focus only on the negative implications (Tassin and Kull 2015). There are many invasive species globally that have mostly negative impacts and a lot of work elsewhere focuses on reporting and quantifying just these negative social effects as opposed to more balanced views (Shackleton et al. 2019c). 
This difference in South Africa is likely because of a focus on livelihoods, rather than a species-centred framing. We suggest therefore that more people-centred frameworks could be useful to promote more integrated understanding of invasions and their effects on human wellbeing. For improving further understanding, incorporating larger spatial and temporal frames would be useful. Most studies cover a restricted time period and do not adequately show how longer-term changes in benefits and costs affect people (Shackleton et al. 2007), and what drives the change. Similarly, many studies only focus on one group of actors.

\subsubsection{Proposition 3c: The Negative Social Impacts of Invasive Species on Local Livelihoods are of More Concern to People than Impacts on Biodiversity}

Most of the work on invasion science in South Africa has focused on biological aspects, with relatively little work on the social aspects (Abrahams et al. 2019), and this bias is common globally (Kull and Tassin 2012; Vaz et al. 2017a). Despite this, some South African research has examined the interaction between invasive species and people's livelihoods_-commonly in rural areas (Shackleton et al. 2019c).

Local communities in the Eastern Cape were mainly concerned about the social impacts of A. dealbata (Ngorima and Shackleton 2019) and mentioned the impacts of its roots on buildings, effects on cropping activities, issues with crime, and impacts on cultural sites. A handful of villagers mentioned the impacts of A. dealbata on water resources but none mentioned its impacts on biodiversity. In the Drakensberg region of the Eastern Cape, over 50\% of villagers mentioned the impacts of Acacia invasions on crime rates, while $41 \%$ mentioned their impacts on water supply and security (although the authors note that "one may question whether this is a real perception or one borrowed from the WfW programme" (de Neergaard et al. 2005). Other concerns, voiced by a minority, included their impacts on grazing land and detrimental effects on native species (de Neergaard et al. 2005). In the Kalahari, local communities mentioned eight disservices as a result of Prosopis tree invasions (Shackleton and Shackleton 2018). The highest-ranked disservices were social (water resources, human health, infrastructure); the second lowest-ranked (7th) was its effects on species richness. In the same study, the impacts of invasive O. ficus-indica on human health were ranked highly ( $30 \%$ of respondents), while only $1 \%$ mentioned biodiversity impacts.

Other studies showed that people place importance on the negative impacts of biological invasions on biodiversity, although these impacts are also cited amongst social issues too. For example, communal villages and commercial farmers most commonly mentioned the negative effects of Prosopis on water, followed by loss of grazing on commercial farms, and detrimental effects on native plant biodiversity and to a lesser extent a variety of socioeconomic effects, such as reducing property value, revenue loss and effects on human health and infrastructure (Shackleton et al. 
2015a). The impacts of tree invasions on fynbos biodiversity were considered by rural communities on the Agulhas Plain as a key threat, because it hampered the collection of wild flowers, with impacts on fire and water viewed as an issue only by a minority of the respondents (de la Fontaine 2013). However, in the same area, farmers considered the impacts of invasive trees on water as a major issue, followed by their impacts on livestock health, and grazing and crop land. In Cape Town, people were mainly concerned about the negative effects of invasive species on native biodiversity, followed by impacts on water supply, fire risk, human health and safety (Potgieter et al. 2019).

In summary, it appears that the literature is quite divergent. In some areas and for some social groups, loss of biodiversity is considered as one of the main impacts of invasive species, while in other areas or for other social groups it is hardly considered at all. Therefore, this proposition is not strongly supported. These differences might also be partly caused by the analytical frameworks used, researcher bias, the methods used and the kinds of questions asked. The findings also suggest that in some cases the concern over biological impacts are a manifestation of social values and therefore in reality biodiversity impacts are a threat to social concepts relating to human values and systems (e.g. preservation, heritage, stewardship, protected areas) (Carruthers 1995). Similarly, biodiversity might underpin many social related services or practices, e.g. flower collection or grazing potential.

\subsection{People's Response to Invasive Species}

\subsubsection{Proposition 4a: People are Less Willing to Manage Species Regarded as 'Charismatic'}

Many instances of resistance to invasive species management have arisen within South Africa. Whilst this is undoubtedly a function of the interplay of species traits, stakeholder values and local contexts, resistance is often met due to the charisma of certain species. By "charisma" we mean species that are linked to emotional values such as plants with large, bright flowers or unique growth forms, animals with neoteric features (big eyes and large heads), those that are entertaining and quirky, cute, colourful or those that are majestic, as opposed to less charismatic species which are often thorny, drab, do not have fur, and may sting or bite (Shackleton et al. 2019 b). Characteristics that relate to charisma can overwhelm many other considerations, and can hinder or derail proposed management strategies (Dickie et al. 2014; Gaertner et al. 2016).

Control of the charismatic Anas platyrhynchos (Mallards) was met with significant resistance from local residents in Cape Town (Gaertner et al. 2016). Residents enjoyed these colourful and friendly ducks that provided them with entertainment and pleasure. In particular, they enjoyed feeding them which is not as easy with native ducks. Also, in Cape Town, there was controversy over the control of Hemitragus jemlahicus (Himalayan Tahr), which many residents viewed as majestic 
(see Davies et al. 2020, Chap. 23, Sect. 23.8.2). However, in this instance control continued because the animals were within a national park and so ecological imperatives overrode public sentiment. In Pretoria, residents successfully opposed the listing of J. mimosifolia in the city because it produces an abundance of beautiful purple flowers that residents admire; so much that the city is colloquially known as the Jacaranda City (Dickie et al. 2014). This resonates with the ongoing vocal and active opposition to the control of charismatic Pinus pinea (Umbrella Pine) on Table Mountain (Gaertner et al. 2016).

In other situations, charisma is not at the forefront of opposition to the management of particular species and other human values can inspire opposition. For example, a woman in Makhanda said she would refuse the removal of a $M$. azedarach tree from her garden, not because of its beauty or charisma, but because she had fond memories of her children playing in the tree. On the other hand, some see it as ethically wrong to control invasive alien species. The killing of Columba species (Pigeons), which some might view as uncharismatic, faced a lot of opposition, as it is an animal and people enjoyed seeing them (Harris et al. 2017). Similarly, citizens in Cape Town have responded "Everything can be annoying, because its alive. . we have to accept it" and "You should not kill them, you should move them back to the Eastern Cape" with regards to the management of S. gutturalis (Guttural Toad) that would not traditionally be considered as charismatic (Novoa et al. 2017), and did not come from the Eastern Cape (Telford et al. 2019). Many invasive species provide livelihood benefits, which lead to opposition to their control, and has nothing to do with charisma (Shackleton et al. 2007). The commercial importance of some species, e.g. in forestry or aquaculture, promote resistance to management (van Wilgen and Richardson 2014; Zengeya et al. 2017).

While there was some evidence in support of this proposition, it generally appears that a range of different motivations can catalyse resistance to control efforts, of which species charisma is only one. The relative importance of each motivation can only be tested through carefully chosen experiments with different stakeholders or social groups. Moreover, in socially and culturally diverse countries, like South Africa, the very construct of uniform notions of charisma may be questionable, particularly when more important factors, such as economics, are taken into consideration. Therefore, improved engagement and decision support tools might help to guide and prioritise management in the future (Gaertner et al. 2016; Novoa et al. 2018).

\subsubsection{Proposition 4b: Social Heterogeneity Increases Conflicts Around the Management of Biological Invasions}

South Africa is colloquially known as the "rainbow nation", reflecting its diversity and mixing of multiple ethnic groups, cultures, races, languages and worldviews. We propose that social heterogeneity increases conflicts around invasive species 
management. In South Africa, longstanding conflicts include the listing and control of trout as a sport fish (Woodford et al. 2017), managing commercially important species of forestry trees (van Wilgen and Richardson 2014), and managing charismatic species in urban areas (Dickie et al. 2014; Gaertner et al. 2016). From these few, but prominent, cases, it appears that conflicts around management between the state and other actors are driven more often by elite and middle-class individuals and institutions who have resources, power and influence. More often than not, the voices of the poor and marginalised are not heard and therefore are rarely considered.

The literature does however highlight a conflict situation surrounding Acacia species in communal lands bordering the Golden Gate Highlands National Park in the Free State (Mukwada et al. 2016), showing the different worldviews among the local villagers and park officials. This has resulted in park-community conflicts relating to perceived threats and management responses, which might also partly be a manifestation of other deeper underlying issues relating to land and resource use, land claims and economic benefit-sharing that result from historic injustices to some marginalised ethic groups. Narratives and experiences by heterogeneous groups are not always accounted for, and can therefore increase complexity and conflict surrounding management (Lidström et al. 2016). These authors describe how environmental engagement does not always transcend, but can sometimes increase, ecological and social inequities in South Africa (Lidström et al. 2016).

Overall, we found this proposition hard to test due to a lack of in-depth information surrounding causes of conflict, although we would suggest it is likely to be true. The results of the few mentioned cases suggest that conflicts are often very contextdependent, relating to different species and different issues (e.g. ethical vs economic debates) and can be a manifestation of other deeper issues often relating to heterogeneity. However, most of the reported conflicts surround elite citizen interests and conservationists rather than between different groups of citizens. However, many studies focus on one specific set of actors or lump all citizens into one group with a lack of comparison between different actors.

\subsubsection{Proposition 4c: Engagement with Society is Key to Successful Management}

It is increasingly acknowledged that involving people in the development and implementation of management is crucial for the success of natural resource conservation programmes (Ntshotsho et al. 2015; Turner et al. 2016; Novoa et al. 2018). With specific reference to the management of biological invasions, South Africa is unique, because it has the renowned Working for Water programme which has both social and ecological goals. Due to the large variety of social and ecological contexts, as well as the diversity of invasive species in the country, South Africa has been very forward thinking in engaging with different actors and stakeholders to develop policies and management actions aimed at solving contentious issues and ensuring the long-term stability of management through benefiting society (van 
Wilgen and Wannenburgh 2016). Research conceptualised in South Africa has led to the development of a stakeholder engagement framework (Novoa et al. 2018).

A number of projects in South Africa have worked with stakeholders to understand how to implement control programs more effectively. Urgenson et al. (2013) highlighted that many private landowners in South Africa understand the need to share management responsibility with the state. However, many of these landowners also emphasised the need for financial and other incentives to improve compliance, but there was a lack of agreement on what these should be. Harris et al. (2017) highlighted that manager's views and methods for control differed very much from the perceptions and desires of staff at the University of South Africa. They suggested that public participation would be needed to develop appropriate management strategies. A number of other projects have engaged with a broad set of actors to help plan and prioritise management strategies. Suggested approaches have included stakeholder workshops, and decision-making tools to develop spatial prioritisation plans (e.g. Roura-Pascual et al. 2009; Forsyth et al. 2012) and adaptation responses (Shackleton et al. 2016). These interventions have led to the development of special prioritisation plans for parts of the Western Cape (e.g. Forsyth et al. 2012), and national taxon-specific plans as in the case of Prosopis (Shackleton et al. 2017) and Cactaceae (Kaplan et al. 2017) —although current uptake of these plans is poor (see van Wilgen et al. 2020a, b, Sect. 21.4).

In working through contentious issues, some engagement processes have been highly successful (Novoa et al. 2016), while others have resulted in little change (Woodford et al. 2016). Novoa et al. (2016) showed that, for controlling cacti in South Africa, engagement increased understanding between opposing parties (those promoting different species for ornamental and production purposes, conservationists worried about invasions, and landowners affected by their impacts) and led to better recognition of each other's viewpoints. Furthermore, through engagement, opposing actors came to consensus relatively easily on which taxa in the Cactaceae should be listed as invasive under the National Environmental Management: Biodiversity Act (NEM:BA) regulations (see van Wilgen et al. 2020a, Chap. 1; van Wilgen et al. 2020b, Chap. 21; Box 1.2). Only certain genera and growth forms that are more likely to be invasive were listed, allowing for the use and trade of all others (Novoa et al. 2015a). This allowed for win-win outcomes for both parties. This successful example was due to having a good understanding of Cactaceae ecology, but also having open and bottom-up discussions.

For highly established and profitable industries, such as forestry, engagement has been more difficult (van Wilgen and Richardson 2014; Woodford et al. 2016). These industries have powerful lobby groups and economic interests, making compromise more difficult to achieve. Another big conflict issue has been in listing trout, where engagement has been confrontational and has potentially even worsened the situation. A number of powerful, elite fishers almost derailed the creation of invasive species lists as required under NEM:BA in South Africa. Much of this is to do with elite "recreational selfishness" but there are also economic arguments to be made, with trout fisheries contributing to the economies of a number of small towns across South Africa. The conservation actors were willing to allow mutually beneficial 
strategies, in which some areas now stocked with trout would be re-prioritised for biodiversity conservation while other localities would allow trout fishing. But proposals for compromise solutions were not accepted by the trout fishing fraternity (Brown 2013, 2016), and because the government is insistent on listing trout, the issue may still end up in court (Ellender et al. 2014). This is driven by a lack of trust in authorities, inadequate communication and understanding (Cox 2013), a similar issue in other regions of the world (Wald et al. 2019). In contrast, Bass (Micropterus species) anglers have been more supportive of management suggestions and have engaged with researchers in citizen science projects to control and monitor invasive fish (Weyl et al. 2014). The different outcomes of trout and bass anglers engagement comes down to context. While bass fishing primarily takes place in human-made dams and reservoirs that are already disturbed, allowing for invasives to be present (not needing control), the best trout-fishing takes place in undisturbed mountain rivers with endemic native fishes threatened by trout predation, making regulation desirable (see Davies et al. 2020, Sect. 23.5).

Our proposition finds some support and we have shown instances where engagement has been highly beneficial, but also other cases where it has been difficult. Moreover, most research on management and engagement seeks to improve knowledge as opposed to finding ways to implement it, i.e. there is a researchimplementation gap (see Foxcroft et al. 2020, Chap. 27). Involvement of non-research stakeholders can help to swing the balance and thus there is need for better engagement with different actors (Ntshotsho et al. 2015). Often there are social-ecological barriers that can be addressed by meaningful engagement and collaboration (Esler et al. 2010, Shackleton et al. 2016; Angelstam et al. 2017). Having more bottom-up and collaborative management that involves co-design and co-implementation could improve control in the long-term (Reed et al. 2017). Also, better understanding why, where and how engagement works, or doesn't, would benefit planning in the future. South Africa could also learn lessons from elsewhere. For example, from the successful collaboration between parties to better control mink invasions in Scotland (Bryce et al. 2011), and the role of citizen science and volunteering in many parts of Europe (Adriaens et al. 2015; Pagès et al. 2019).

\subsection{Conclusions}

The chapter has highlighted the important role of human and social dimensions of invasion science in South Africa. Work on this topic in the country has provided better understanding of a number of aspects relating to invasion processes and impacts, and has in some cases improved management responses. South African research has contributed much toward understanding the effects of biological invasions on people's livelihoods, particularly in poor rural areas (e.g. de Neergaard et al. 2005; Shackleton et al. 2007). Historians have theorised the role of past social processes in facilitating invasions and their management (Carruthers et al. 2011; Bennett and van Sittert 2019). Social studies have also helped in developing 
engagement and management processes to be used in South Africa and elsewhere (Forsyth et al. 2012; Novoa et al. 2015b, 2018). Due to different social-ecological settings within the country, work in South Africa has also shed light on how and why people contextualise biological invasions, and why conflicts arise (Lidström et al. 2016; Shackleton et al. 2015a; Potgieter et al. 2019).

Despite its importance, the volume of work in the social domain still lags behind ecologically-focused research, both in South Africa and elsewhere, and there are many pressing areas and questions where further and deeper contributions are needed. In this chapter we investigated social science and humanities contributions for 12 pertinent propositions, covering four broad topics, using South Africa as a case study region. We found that that substantial evidence was lacking for supporting all but one of these propositions (Table 24.1). Similarly, only five of the 12 propositions could be fully supported (Table 24.1). Those that were unsupported have contradictory information or lack concrete evidence, making further work necessary.

A number of gaps and opportunities were identified relating to the four broad thematic areas outlined in Shackleton et al. (2019a). Regarding people causing invasions, there is need for better examining the role of different sectors of society, and effectively incorporating human actions into models of invasion processes. Concerning people conceptualising invasions, studies have revealed that public knowledge about biological invasions and their effects is low in most, albeit not all, situations, particularly in urban areas. Several techniques from the education and social disciplines could be used to improve public education and awareness, which could lead to more informed and collaborative management efforts in the future (see Byrne et al. 2020, Chap. 25). Better understanding the social-ecological contexts and knowledge systems under which people conceptualise biological invasions would also be beneficial.

Many studies investigating the effects of biological invasion only focus on one group of actors. However, invasions are complex and can have different effects for different groups of people and these can lead to conflicts and trade-offs, and more research is needed to assess this. Most research also lacks deeper considerations of various power dynamics and outcomes relating to the impacts of biological invasions. Such work requires historical nuance, grounding in the social realities of different geographic and institutional contexts, and attention to relationships, practices, perceptions, and discourses. Moreover, a few large-scale cost-benefit analyses have been conducted, but assessing benefits and costs and value chains of invasive species at local levels and between different actors could help to improve understanding and management planning. Linking biological impacts to human wellbeing would also provide further evidence to guide or justify management. Lastly, relating to responding to invasions, increased collaborative research and management planning involving various actors could help to shape better policy, and to effectively control biological invasions in the country (Novoa et al. 2018; Shackleton et al. 2019d). Also, a better understanding of in which forms and the contexts engagement works, and what makes engagement activities fail would help 
to guide future actions. This might link to improved analysis and understanding of power dynamics and social networks.

In conclusion, structuring this chapter around a series of propositions has highlighted what is known and what is not, whilst simultaneously reviewing meaningful social science theory on biological invasions in South Africa and beyond. Further work in the area should be promoted; South Africa is a superb place to test theories and advance knowledge regarding social dimensions, because of its complex and diverse social-ecological setting and well-developed research capacity (van Wilgen et al. 2020a, b, Chap. 1, Chap. 21).

Acknowledgements RTS acknowledges the Swiss government for funding. CMS's participation was funded by the South African Research Chairs Initiative of the Department of Science and Technology and the National Research Foundation of South Africa (any opinion, finding, conclusion or recommendation expressed is that of the authors and the NRF does not accept any liability). AN acknowledges funding from EXPRO grant no. 19-28807X (Czech Science Foundation) and long-term research development project RVO 67,985,939 (The Czech Academy of Sciences). We thank the reviewers and editors for their valuable inputs which helped to substantially improve the chapter.

\section{References}

Abrahams B, Sitas N, Esler KJ (2019) Exploring the dynamics of research collaborations by mapping social networks in invasion science. J Environ Manag 229:27-37. https://doi.org/10. 1016/j.jenvman.2018.06.051

Adriaens T, Sutton-Croft M, Owen K et al (2015) Trying to engage the crowd in recording invasive alien species in Europe: experiences from two smartphone applications in northwest Europe. Manage Biol Invasions 6:215-225. https://doi.org/10.3391/mbi.2015.6.2.12

Aitken M, Rangan H, Kull CA (2009) Living with alien invasives. The political ecology of wattle in the eastern highveld Mpumalanga, South Africa. Etudes Océan Indien 42:115-141. https://doi. org/10.4000/oceanindien.769

Alletson DJ (1997) One hundred years of trout in Natal. Piscator 129:80-87

Angelstam P, Barnes G, Elbakidze M et al (2017) Collaborative learning to unlock investments for functional ecological infrastructure: bridging barriers in social-ecological systems in South Africa. Ecosyst Serv 27:291-304. https://doi.org/10.1016/j.ecoser.2017.04.012

Beinart W, Wotshela L (2003) Prickly pear in the Eastern Cape since the 1950s - perspectives from interviews. Environ Hist 29:191-209

Beinart W, Wotshela L (2012) Prickly pear: the social history of a plant in the Eastern Cape. Wits University Press, Johannesburg. https://doi.org/10.18772/22011115300

Bennett BM (2011) Naturalising Australian trees in South Africa: climate, exotics and experimentation. J South Afr Stud 37:265-280. https://doi.org/10.1080/03057070.2011.579434

Bennett BM (2014) Model invasions and the development of national concerns over invasive introduced trees: insights from South African history. Biol Invasions 16:499-512. https://doi. org/10.1007/s10530-013-0601-1

Bennett BM (2015) Margaret Levyns and the decline of ecological liberalism in the Southwestern Cape, 1890-1975. S Afr Hist J 67:64-84. https://doi.org/10.1080/02582473.2015.1019358

Bennett BM, Kruger FJ (2015) Forestry and water conservation in South Africa: history. In: Science and policy. ANU Press, Canberra. https://doi.org/10.22459/FWCSA.11.2015 
Bennett BM, van Sittert L (2019) Perceptions of invasive alien plants in South Africa: historicising the national framework. J Environ Manag 229:174-181. https://doi.org/10.1016/j.jenvman. 2018.07.029

Blanchard R, Richardson DM, O'Farrell PJ et al (2011) Biofuels and biodiversity in South Africa. S Afr J Sci 107(5/6):186. https://doi.org/10.4102/sajs.v107i5/6.186

Brewbaker JL (1987) Leucaena: a multipurpose tree genus for tropical agroforestry. In: Steppler HA, Nair PKR (eds) Agroforestry, a decade of development. International Council for Research in Agroforestry (ICRAF), Nairobi

Britz P (2015) The history of South African inland fisheries policy with governance recommendations for the democratic era. Water SA 41:624-632. https://doi.org/10.4314/wsa.v41i5.5

Brown D (2013) Are trout South African? Stories of fish, people and places. Picador Africa, Johannesburg

Brown D (2016) Native, natural, indigenous, indigenised? Trout in the postcolony. Crit Afr Stud 8:179-195. https://doi.org/10.1080/21681392.2016.1211848

Bryce R, Oliver MK, Davies L et al (2011) Turning back the tide of American mink invasion at an unprecedented scale trough community participation and adaptive management. Biol Conserv 144:575-583. https://doi.org/10.1016/j.biocon.2010.10.013

Byrne MJ, du Plessis D, Ivey PJ et al (2020) Education, training and capacity building in the field of biological invasions in South Africa. In: van Wilgen BW, Measey J, Richardson DM, Wilson JR, Zengeya TA (eds) Biological invasions in South Africa. Springer, Berlin, pp 727-754. https://doi.org/10.1007/978-3-030-32394-3_25

Canavan S, Richardson DM, Le Roux JJ et al (2018) Alien bamboos in South Africa: a sociohistorical perspective. Human Ecol 47:121-133. https://doi.org/10.1007/s10745-018-0041-8

Carruthers J (1995) The Kruger National Park: a social and political history. University of Natal Press, Pietermaritzburg

Carruthers J, Robin L, Hattingh JP et al (2011) A native at home and abroad: the history, politics, ethics and aesthetics of Acacia. Divers Distrib 17:810-821. https://doi.org/10.1111/j.14724642.2011.00779.x

Cole E, Keller RP, Garbach K (2019) Risk of invasive species spread by recreational boaters remains high despite widespread adoption of conservation behaviours. J Environ Manag 229:112-119. https://doi.org/10.1016/j.jenvman.2018.06.078

Comaroff J, Comaroff L (2001) Naturing the nation: aliens, apocalypse and the postcolonial state. J S Afr Stud 27:627-651. https://doi.org/10.1080/13632430120074626

Cox I (2013) Is this the end of the line for freshwater fishing? Farm Wkly 13036:8-9

Davies SJ, Clusella-Trullas S, Hui C et al (2013) Farm dams facilitate amphibian invasion: extralimital range expansion of the painted reed frog in South Africa. Austral Ecol 38:851-863. https://doi.org/10.1111/aec.12022

Davies SJ, Jordaan M, Karsten M et al (2020) Experience and lessons from alien and invasive animal control projects in South Africa. In: van Wilgen BW, Measey J, Richardson DM et al (eds) Biological invasions in South Africa. Springer, Berlin, pp 625-660. https://doi.org/10. 1007/978-3-030-32394-3_22

de la Fontaine S (2013) Assessing the values and impacts of invasive alien plants on the livelihoods of rural land-users on the Agulhas Plain South Africa. MS thesis, Stellenbosch University

de Neergaard A, Saarnak C, Hill T, Khanyile M, Berzosa AM, Birch-Thomsen T (2005) Australian wattle species in the Drakensberg region of South Africa-an invasive alien or a natural resource? Agric Syst 85(3):216-233. https://doi.org/10.1016/j.agsy.2005.06.009

de Wit MP, Crookes DJ, van Wilgen BW (2001) Conflicts of interest in environmental management: estimating the costs and benefits of a tree invasion. Biol Invasions 3:167-178. https://doi. org/10.1023/A:1014563702261

Dickie IA, Bennett BM, Burrows LE et al (2014) Conflicting values: ecosystem services and invasive tree management. Biol Invasions 16:705-719. https://doi.org/10.1007/s10530-0130609-6 
Donaldson JE, Hui C, Richardson DM et al (2014) Invasion trajectory of alien trees: the role of introduction pathway and planting history. Glob Chang Biol 20:1527-1537. https://doi.org/10. $1111 / \mathrm{gcb} .12486$

Ellender BR, Weyl OLF, Winker H et al (2010) Quantifying the annual fish harvest from South Africa's largest freshwater reservoir. Water SA 36:45-52. https://doi.org/10.4314/wsa. v36i1.50906

Ellender BR, Woodford DJ, Weyl OLF et al (2014) Managing conflicts arising from fisheries enhancements based on non-native fishes in southern Africa. J Fish Biol 85:1890-1906. https:// doi.org/10.1111/jfb. 12512

Esler KJ, Prozesky H, Sharma GP et al (2010) How wide is the "knowing-doing" gap in invasion biology? Biol Invasions 12:4065-4075. https://doi.org/10.1007/s10530-010-9812-x

Estévez RA, Anderson CB, Pizarro JC et al (2015) Clarifying values, risk perceptions and attitudes to resolve or avoid social conflicts in invasive species management. Conserv Biol 29:19-30. https://doi.org/10.1111/cobi.12359

Faulkner KT, Robertson MP, Rouget M et al (2017) Prioritising surveillance for alien organisms transported as stowaways on ships travelling to South Africa. PLoS One 12:0173340. https:// doi.org/10.1371/journal.pone.0173340

Faulkner KT, Burnsess A, Byrne M et al (2020) South Africa's pathways of introduction and dispersal and how they have changed over time. In: van Wilgen BW, Measey J, Richardson DM et al (eds) Biological invasions in South Africa. Springer, Berlin, pp 311-352. https://doi.org/10. 1007/978-3-030-32394-3_12

Forsyth GG, Le Maitre DC, O'Farrell PJ et al (2012) The prioritisation of invasive alien plant control projects using a multi-criteria decision model informed by stakeholder input and spatial data. J Environ Manag 103:51-57. https://doi.org/10.1016/j.jenvman.2012.01.034

Foxcroft LC, van Wilgen BW, Abrahams B et al (2020) Knowing-doing continuum or knowingdoing gap? Information flow between researchers and managers of biological invasions in South Africa. In: van Wilgen BW, Measey J, Richardson DM et al (eds) Biological invasions in South Africa. Springer, Berlin, pp 827-850. https://doi.org/10.1007/978-3-030-32394-3_28

Gaertner M, Larson BM, Irlich UM et al (2016) Managing invasive species in cities: a framework from Cape Town, South Africa. Land Urban Plan 151:1-9. https://doi.org/10.1016/j. landurbplan.2016.03.010

Grove RH (1995) Green imperialism. Cambridge University Press, Cambridge

Harris E, De Crom EP, Wilson A (2016) Pigeons and people: mortal enemies or lifelong companions? A case study on staff perceptions of the pigeons on the University of South Africa, Muckleneuk campus. J Public Aff 16:331-340. https://doi.org/10.1002/pa.1593

Harris E, De Crom EP, Wilson A (2017) Staff perceptions of pigeons control strategies on the University of South Africa, Muckleneuk campus. J Trans Res S Afr 13:a399. https://doi.org/10. 4102/td.v13i1.399

Head L (2017) The social dimensions of invasive plants. Nat Plants 3:17075. https://doi.org/10. 1038/nplants.2017.75

Hecht PJ (1992) The current status, future prospects and environmental implications of mariculture in South Africa. S Afr J Sci 88:335-342

Hill MP, Moran VC, Hoffmann JH et al (2020) More than a century of biological control against invasive alien plants in South Africa: a synoptic view of what has been accomplished. In: van Wilgen BW, Measey J, Richardson DM et al (eds) Biological invasions in South Africa. Springer, Berlin, pp 549-568. https://doi.org/10.1007/978-3-030-32394-3_19

Humair F, Humair L, Kuhn F et al (2015) E-commerce trade in invasive plants. Conserv Biol 29:1658-1665. https://doi.org/10.1111/cobi.12579

Janick J (2007) Plant exploration: from Queen Hatshepsut to Sir Joseph Banks. Hort Sci 42:191-196. https://doi.org/10.21273/HORTSCI.42.2.191

Kannan R, Shackleton CM, Shaanker RU (2013) Reconstructing the history of introduction and spread of the invasive species, Lantana, at three spatial scales in India. Biol Invasions 15:1287-1302. https://doi.org/10.1007/s10530-012-0365-z 
Kaplan H, Wilson JR, Klein H et al (2017) A proposed national strategic framework for the management of Cactaceae in South Africa. Bothalia 47(2):a2149. https://doi.org/10.4102/abc. v47i2.2149

Kleunen $\mathrm{v}$ et al (2018) The changing role of ornamental horticulture in alien plant invasion. Biol Rev 93:1421-1437. https://doi.org/10.1111/brv.12402

Kraaij T, Baard JA, Arndt J et al (2018) An assessment of climate, weather and fuel factors influencing a large, destructive wildfire in the Knysna region, South Africa. Fire Ecol 14:4. https://doi.org/10.1186/s42408-018-0001-0

Kueffer C (2017) Plant invasions in the Anthropocene. Science 358:724-725. https://doi.org/10. $1126 /$ science.aao6371

Kull CA (2018) Critical invasion science: weeds, pests, and aliens. In: Lave R, Biermann C, Lane SN (eds) The Palgrave handbook of critical physical geography. Palgrave Macmillan, Cham. https://doi.org/10.1007/978-3-319-71461-5_12

Kull CA, Tassin J (2012) Australian acacias: useful and (sometimes) weedy. Biol Invasions 14:2229-2233. https://doi.org/10.1007/s10530-012-0244-7

Kull CA, Shackleton CM, Cunningham PJ et al (2011) Adoption, use and perception of Australian acacias around the world. Divers Distrib 17:822-836. https://doi.org/10.1111/j.1472-4642. 2011.00783.x

Kull CA, Harimanana SL, Radaniela Andrianoro A et al (2019) Perceiving the "neo-Australian" forests of lowland eastern Madagascar: invasions, transitions, and livelihoods. J Environ Manag 229:48-46. https://doi.org/10.1016/j.jenvman.2018.06.004

Le Maitre DC, Richardson DM, Chapman RA (2004) Alien plant invasions in South Africa: driving forces and the human dimension. S Afr J Sci 100:103-112

Le Maitre DC, Gaertner M, Marchante E et al (2011) Impacts of invasive Australian acacias: implications for management and restoration. Divers Distrib 17:1015-1029. https://doi.org/10. 1111/j.1472-4642.2011.00816.x

Le Maitre DC, Blignaut JN, Clulow A et al (2020) Impacts of plant invasions on terrestrial water flows in South Africa. In: van Wilgen BW, Measey J, Richardson DM et al (eds) Biological invasions in South Africa. Springer, Berlin, pp 429-456. https://doi.org/10.1007/978-3-03032394-3_15

Le Roux JJ, Richardson DM, Wilson JR et al (2013) Human usage in the native range may determine future genetic structure of an invasion: insights from Acacia pycnantha. BMC Ecol 13:37. https://doi.org/10.1186/1472-6785-13-37

Lidström S, West S, Katzschner T et al (2016) Invasive narratives and the inverse of slow violence: alien species in science and society. Environ Human 7:1-40. https://doi.org/10.1215/220119193616317

Louw WJA (2004) General history of the South African forestry industry: 1891 to 2002. S Afr For J 201:65-76. https://doi.org/10.1080/20702620.2004.10431775

Low T (2012) In denial about dangerous aid. Biol Invasions 14:2235-2236. https://doi.org/10. 1007/s10530-012-0264-3

Mabin CA, Wilson JRU, Le Roux JJ et al (2017) Reassessing the invasion of South African waters by the European shore-crab Carcinus maenas. Afr J Marine Sci 39:259-267. https://doi.org/10. 2989/1814232X.2017.1363818

Martin GD, Coetzee JA (2011) Pet stores, aquarists and the internet trade as modes of introduction and spread of invasive macrophytes in South Africa. Water SA 37:371-380. https://doi.org/10. 4314/wsa.v37i3.68488

Measey J, Hui C, Somers M (2020) Terrestrial vertebrate invasions in South Africa. In: van Wilgen BW, Measey J, Richardson DM, Wilson JR, van Wilgen BW (eds) Biological invasions in South Africa. Springer, Berlin, pp 113-150. https://doi.org/10.1007/978-3-030-32394-3_5

Measey J, Davies SJ, Vimercati G et al (2017) Invasive amphibians in southern Africa: a review of invasion pathways. Bothalia-African. Biodivers Conserv 47:1-12. https://doi.org/10.4102/abc. v47i2.2117

Milton SJ (2004) Grasses as invasive alien plants in South Africa. S Afr J Sci 100:69-75 
Mukwada G, Chingombe W, Taru P (2016) Strifes of the frontier: an assessment of Acacia mearnsii related park-community conflicts in the Golden Gate highlands National Park, South Africa. J Integr Environ Sci 13:37-54. https://doi.org/10.1080/1943815X.2015.1130062

Ngorima A, Shackleton CM (2019) Livelihood benefits and costs of an invasive alien tree (Acacia dealbata) to rural communities in the Eastern cape, South Africa. J Environ Manag 229:158-165. https://doi.org/10.1016/j.jenvman.2018.05.077

Novoa A, Le Roux JJ, Robertson MP et al (2015a) Introduced and invasive cactus species: a global review. AOB Plants 7:pul078. https://doi.org/10.1093/aobpla/plu078

Novoa A, Kaplan H, Kumschick S et al (2015b) Soft touch or heavy hand? Legislative approaches for preventing invasions: insights from cacti in South Africa. Invasive Plant Sci Manage 8:307-316. https://doi.org/10.1614/IPSM-D-14-00073.1

Novoa A, Kaplan H, Wilson JRU et al (2016) Resolving a prickly situation: involving stakeholders in invasive cactus management in South Africa. Environ Manag 57:998-1008. https://doi.org/ 10.1007/s00267-015-0645-3

Novoa A, Dehnen-Schmutz K, Fried J, Vimercati G (2017) Does public awareness increase support for invasive species management? Promising evidence across taxa and landscape types. Biol Invasions 19(12):3691-3705. https://doi.org/10.1007/s10530-017-1592-0

Novoa A, Shackleton RT, Canavan S et al (2018) A framework for engaging stakeholders on the management of alien species. J Environ Manag 205:286-297. https://doi.org/10.1016/j. jenvman.2017.09.059

Ntshotsho P, Prozesky HE, Esler KJ et al (2015) What drives the use of scientific evidence in decision making? The case of the South African working for water program. Biol Conserv 184:136-144. https://doi.org/10.1016/j.biocon.2015.01.021

O'Connor T, van Wilgen BW (2020) The impact of alien plants on rangelands in South Africa. In: van Wilgen BW, Measey J, Richardson DM et al (eds) Biological invasions in South Africa. Springer, Berlin, pp 457-486. https://doi.org/10.1007/978-3-030-32394-3_16

Pagès M, van der Wal R, Lambin X et al (2019) Involving volunteers in rationalised nature conservation: challenges and opportunities in the case of non-native species management in Great Britain. J Environ Manag 229:102-111. https://doi.org/10.1016/j.jenvman.2018.06.053

Peacock DS, van Rensburg BJ, Robertson MP (2007) The distribution and spread of the invasive alien common myna, Acridotheres tristis L. (Aves: Sturnidae), in southern Africa. S Afr J Sci 103:465-473

Pooley S (2014) Burning Table Mountain: an environmental history of fire on the Cape Peninsula. Palgrave Macmillan, Basingstoke. https://doi.org/10.1057/9781137415448

Potgieter LJ, Gaertner M, O'Farrell PJ et al (2019) Perceptions of impact: invasive alien plants in the urban environment. J Environ Manag 229:76-87. https://doi.org/10.1016/j.jenvman.2018. 05.080

Pouris A (2007) The international performance of the South African academic institutions: a citation assessment. Higher Educ 54:501-509. https://doi.org/10.1007/s10734-006-9034-4

Pyšek P, Richardson DM, Jarošík V (2006) Who cites who in the invasion zoo: insights from an analysis of the most highly cited articles in invasion ecology. Preslia 78:437-468

Reed MS, Vella S, Sidoli del Ceno J et al (2017) A theory of participation: what makes stakeholder engagement and public engagement in environmental management work? Restor Ecol 26:S7S17. https://doi.org/10.1111/rec.12541

Richardson DM, Cambray JA, Chapman RA et al (2003) Vectors and pathways of biological invasions in South Africa - past, present and future. In: Ruiz G, Carlton J (eds) Invasive species: vectors and management strategies. Island Press, Washington DC, pp 292-349

Richardson DM, Abrahams B, Boshoff N et al (2020) South Africa's Centre for Invasion Biology: an experiment in invasion science for society. In: van Wilgen BW, Measey J, Richardson DM, Wilson JR, Zengeya TA (eds) Biological invasions in South Africa. Springer, Berlin, pp 875-912. https://doi.org/10.1007/978-3-030-32394-3_30

Roura-Pascual N, Richardson DM, Krug RM et al (2009) Ecology and management of alien plant invasions in South African fynbos: accommodating key complexities in objective decision making. Biol Conserv 142:1595-1604. https://doi.org/10.1016/j.biocon.2009.02.029 
Seebens H, Blackburn TM, Dyer EE et al (2017) No saturation in the accumulation of alien species worldwide. Nat Commun 8:14435. https://doi.org/10.1038/ncomms14435

Shackleton CM, Shackleton RT (2016) Knowledge, perceptions and willingness to control designated invasive tree species in urban household gardens in South Africa. Biol Invasions 18:1599-1609. https://doi.org/10.1007/s10530-016-1104-7

Shackleton SE, Shackleton RT (2018) Local knowledge regarding ecosystem services and disservices from invasive alien plants in the arid Kalahari, South Africa. J Arid Environ 159:22-33. https://doi.org/10.1016/j.jaridenv.2017.07.001

Shackleton CM, McGarry D, Fourie S et al (2007) Assessing the effects of invasive alien species on rural livelihoods: case examples and a framework from South Africa. Hum Ecol 35:113-127. https://doi.org/10.1007/s10745-006-9095-0

Shackleton SE, Kirby D, Gambiza J (2011) Invasive plants - friends or foes? Contribution of prickly pear (Opuntia ficus-indica) to livelihoods in Makana Municipality, Eastern Cape, South Africa. Dev South Afr 28:177-193. https://doi.org/10.1080/0376835X.2011.570065

Shackleton RT, Le Maitre DC, Pasiecznik NM, Richardson DM (2014) Prosopis: a global assessment of the biogeography, benefits, impacts and management of one of the world's worst woody invasive plant taxa. AoB Plants 6:plu027. https://doi.org/10.1093/aobpla/plu027

Shackleton RT, Le Maitre DC, Richardson DM (2015a) Stakeholder perceptions and practices regarding Prosopis (mesquite) invasions and management in South Africa. Ambio 44:569-581. https://doi.org/10.1007/s13280-014-0597-5

Shackleton RT, Le Maitre DC, van Wilgen BW et al (2015b) Use of non-timber forest products from invasive alien Prosopis species (mesquite) and native trees in South Africa: implications for management. For Ecosys 2:16. https://doi.org/10.1186/s40663-015-0040-9

Shackleton RT, Le Maitre DC, van Wilgen BW et al (2016) Identifying barriers to effective management of widespread invasive alien trees: Prosopis species (mesquite) in South Africa as a case study. Glob Environ Chang 38:183-194. https://doi.org/10.1016/j.gloenvcha.2016.03. 012

Shackleton RT, Le Maitre DC, van Wilgen BW et al (2017) Towards a national strategy to optimise the management of a widespread invasive tree (Prosopis species; mesquite) in South Africa. Ecosyst Serv 27:242-252. https://doi.org/10.1016/j.ecoser.2016.11.022

Shackleton RT, Biggs R, Richardson DM et al (2018) Social-ecological drivers and impacts of invasion-related regime shifts: consequences for ecosystem services and human wellbeing. Envion Sci Policy 89:300-314. https://doi.org/10.1016/j.envsci.2018.08.005

Shackleton RT, Larson BHL, Novoa A et al (2019a) The human and social dimensions in invasion science. J Environ Manag 229:1-9. https://doi.org/10.1016/j.jenvman.2018.08.041

Shackleton RT, Richardson DM, Shackleton CM et al (2019b) Explaining people's perceptions of invasive alien species: a conceptual framework. J Environ Manag 229:10-26. https://doi.org/10. 1016/j.jenvman.2018.04.045

Shackleton RT, Shackleton CM, Kull CA (2019c) The role of invasive alien species in shaping local livelihoods and human well-being. J Environ Manag 229:145-157. https://doi.org/10.1016/j. jenvman.2018.05.007

Shackleton RT, Adriaens T, Brundu G et al (2019d) Stakeholder engagement in the study and management of invasive alien species: a review. J Environ Manag 229:88-101. https://doi.org/ 10.1016/j.jenvman.2018.04.044

Speziale K, Lambertucci S, Carrete M et al (2012) Dealing with non-native species: what makes the difference in South America? Biol Invasions 14:1609-1621. https://doi.org/10.1007/s10530011-0162-0

Tassin J, Kull CA (2015) Facing the broader dimensions of biological invasions. Land Use Policy 42:165-169. https://doi.org/10.1016/j.landusepol.2014.07.014

Telford N, Channing A, Measey J (2019) Origin of invasive populations of the Guttural toad Sclerophrys gutturalis. Herpetol Conserv Biol 14(2):380-392

Tewari DD (2001) Is commercial forestry sustainable in South Africa? The changing institutional and policy needs. For Policy Econ 2:333-353. https://doi.org/10.1016/S1389-9341(01)00028-4 
Thompson WW (1913) The sea fisheries of the Cape Colony. Maskew Miller, Cape Town

Turner BL II, Esler KJ, Bridgewater P et al (2016) Socio-environmental systems (SES) research: what have we learned and how can we use this information in future research programs. Curr Opin Environ Sustain 19:160-168. https://doi.org/10.1016/j.cosust.2016.04.001

Udo N, Darrot C, Atlan A (2019) From useful to invasive, the status of gorse on Reunion Island. J Environ Manag 229:166-173. https://doi.org/10.1016/j.jenvman.2018.06.036

Urgenson LS, Prozesky HE, Esler KJ (2013) Stakeholder perceptions of an ecosystem services approach to clearing invasive alien plants on private land. Ecol Soc 18:26. https://doi.org/10. 5751/ES-05259-180126

van Sittert L (2000) The seed blows about in every Breeze': noxious weed eradication in the Cape Colony, 1860-1909. J South Afr Stud 26:655-674. https://doi.org/10.1080/713683604

van Sittert L (2002) 'Our irrepressible fellow-colonist': the biological invasion of prickly pear (Opuntia ficus-indica) in the Eastern Cape c. 1890-c. 1910. J Hist Geogr 28:397-419. https:// doi.org/10.1006/jhge.2001.0457

van Sittert L (2003) Making the Cape Floral Kingdom: the discovery and defence of indigenous flora at the Cape ca. 1890-1939. Landsc Res 28:113-129. https://doi.org/10.1080/ 01426390306529

van Wilgen BW, Richardson DM (2014) Challenges and trade-offs in the management of invasive alien trees. Biol Invasions 16:721-734. https://doi.org/10.1007/s10530-013-0615-8

van Wilgen BW, Wannenburgh A (2016) Co-facilitating invasive species control, water conservation and poverty relief: achievements and challenges in South Africa's working for water programme. Curr Opin Environ Sustain 19:7-17. https://doi.org/10.1016/j.cosust.2015.08.012

van Wilgen BW, Davies SJ, Richardson DM (2014) Invasion science for society: a decade of contributions from the Centre for Invasion Biology. S Afr J Sci 110(7/8):12. https://doi.org/10. 1590/sajs.2014/a0074

van Wilgen BW, Measey J, Richardson DM et al (2020a) Biological invasions in South Africa: an overview. In: van Wilgen BW, Measey J, Richardson DM et al (eds) Biological invasions in South Africa. Springer, Berlin, pp 3-30. https://doi.org/10.1007/978-3-030-32394-3_1

van Wilgen BW, Wilson JR, Wannenburgh A et al (2020b) The extent and effectiveness of alien plant control projects in South Africa. In: van Wilgen BW, Measey J, Richardson DM et al (eds) Biological invasions in South Africa. Springer, Berlin, pp 593-624. https://doi.org/10.1007/ 978-3-030-32394-3_22

Vaz AS, Kueffer C, Kull CA et al (2017a) The progress of interdisciplinarity in invasion science. Ambio 46:428-442. https://doi.org/10.1007/s13280-017-0897-7

Vaz AS, Kueffer C, Kull CA et al (2017b) Integrating ecosystem services and disservices: insights from plant invasions. Ecosyst Serv 23:94-107. https://doi.org/10.1016/j.ecoser.2016.11.017

Vimercati G, Hui C, Davies SJ et al (2017) Integrating age structured and landscape resistance models to disentangle invasion dynamics of a pond-breeding anuran. Ecol Model 356:104-116. https://doi.org/10.1016/j.ecolmodel.2017.03.017

Wald DM, Nelson KA, Gawel AM et al (2019) The role of trust in public attitudes towards invasive species management on Guam: a case study. J Environ Manag 229:133-144

Walker GA, Robertson MP, Gaertner M et al (2017) The potential range of Ailanthus altissima (tree of heaven) in South Africa: the roles of climate, land use and disturbance. Biol Invasions 19:3675-3690. https://doi.org/10.1007/s10530-017-1597-8

Weyl OLF, Finlayson B, Impson D et al (2014) Threatened endemic fishes in South Africa's Cape Floristic Region: a new beginning for the Rondegat River. Fisheries 39:270-279. https://doi. org/10.1080/03632415.2014.914924

Weyl OLF, Ellender B, Wasserman RJ et al (2020) Alien freshwater fauna in South Africa. In: van Wilgen BW, Measey J, Richardson DM, Wilson JR, Zengeya TA (eds) Biological invasions in South Africa. Springer, Berlin, pp 151-182. https://doi.org/10.1007/978-3-03032394-3_6

Wise RM, van Wilgen BW, Le Maitre DC (2012) Costs, benefits and management options for an invasive alien tree species: the case of mesquite in the Northern Cape, South Africa. J Arid Environ 84:80-90. https://doi.org/10.1016/j.jaridenv.2012.03.001 
Witt ABR (2010) Biofuels and invasive species for an African perspective - a review. GCB Bioenergy 2:321-329. https://doi.org/10.1111/j.1757-1707.2010.01063.x

Woodford DJ, Richardson DM, MacIsaac HJ et al (2016) Confronting the wicked problem of managing biological invasions. NeoBiota 31:63-86. https://doi.org/10.3897/neobiota.31.10038

Woodford DJ, Ivey P, Jordaan MS et al (2017) Optimising invasive fish management in the context of invasive species legislation in South Africa. Bothalia 47:1-9. https://doi.org/10.4102/abc. v47i2.2138

Zengeya TA, Booth AJ, Bastos AD et al (2011) Trophic interrelationships between the exotic Nile tilapia, Oreochromis niloticus and indigenous tilapiine cichlids in a subtropical African river system (Limpopo River, South Africa). Environ Biol Fish 92:479-489. https://doi.org/10.1007/ s10641-011-9865-4

Zengeya T, Ivey P, Woodford DJ et al (2017) Managing conflict-generating invasive species in South Africa: challenges and trade-offs. Bothalia 47:1-11. https://doi.org/10.4102/abc.v47i2. 2160

Zimmermann HG, Moran VC (1991) Biological control of prickly pear, Opuntia ficus-indica (Cactaceae), in South Africa. Agri Ecosyst Environ 37:29-35. https://doi.org/10.1016/01678809(91)90137-M

Open Access This chapter is licensed under the terms of the Creative Commons Attribution 4.0 International License (http://creativecommons.org/licenses/by/4.0/), which permits use, sharing, adaptation, distribution and reproduction in any medium or format, as long as you give appropriate credit to the original author(s) and the source, provide a link to the Creative Commons licence and indicate if changes were made.

The images or other third party material in this chapter are included in the chapter's Creative Commons licence, unless indicated otherwise in a credit line to the material. If material is not included in the chapter's Creative Commons licence and your intended use is not permitted by statutory regulation or exceeds the permitted use, you will need to obtain permission directly from the copyright holder. 